\title{
Luminescent Silica Mesoparticles for Protein Transduction
}

Yuri A. Vorotnikov, ${ }^{a, b}$ Tatiana N. Pozmogova, ${ }^{b, c}$ Anastasiya O. Solovieva, ${ }^{b, d}$ Svetlana M. Miroshnichenko, ${ }^{b, d}$ Elena V. Vorontsova, ${ }^{b, d}$ Lidiya V. Shestopalova, ${ }^{c}$ Yuri V. Mironov, ${ }^{a, c}$ Michael A. Shestopalov, ${ }^{a, b, c, d^{*}}$ Olga A. Efremova $a^{b, d, e^{*}}$

aNikolaev Institute of Inorganic Chemistry SB RAS, 3 Acad. Lavrentiev Ave., 630090 Novosibirsk, Russian Federation.

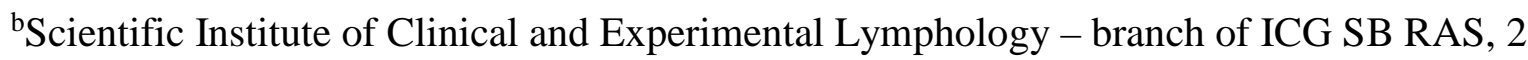
Timakova str., 630060 Novosibirsk, Russian Federation.

${ }^{\mathrm{c}}$ Novosibirsk State University, 2 Pirogova str., 630090 Novosibirsk, Russian Federation. ${ }^{\mathrm{d}}$ Federal Research Center of Fundamental and Translational Medicine, 2 Timakova str., 630117 Novosibirsk, Russian Federation.

eSchool of Mathematics and Physical Sciences, University of Hull, Cottingham Road, HU6 7RX, Hull, UK.

\author{
*Corresponding Authors: \\ *Olga A. Efremova \\ Tel: +441482465417, Fax: +441482466410 \\ e-mail: o.efremova@hull.ac.uk. \\ ** Michael A. Shestopalov \\ Tel. +7-383-330-92-53, Fax +7-383-330-94-89 \\ e-mail: shtopy@niic.nsc.ru
}

Keywords. Octahedral molybdenum cluster, silica, cytotoxicity, cellular uptake, protein transduction.

\begin{abstract}
Unlike silica nanoparticles, the potential of silica mesoparticles (SMPs) (i.e. particles of submicron size) for biological applications in particular the in vitro (let alone in vivo) cellular delivery of biological cargo has so far not been sufficiently studied. Here we examine the potential of luminescent (namely, octahedral molybdenum cluster doped) SMPs synthesised by a simple one-pot reaction for the labelling of cells and for protein transduction into larynx carcinoma (Hep-2) cells using GFP as a model protein. Our data demonstrates that the SMPs internalise into the cells within half an hour. This results in cells that detectably luminesce via conventional methods. In addition, the particles are non-toxic both in darkness and upon photoirradiation. The SMPs were modified to allow their functionalisation by a protein, which then delivered the protein (GFP) efficiently into the cells. Thus, the luminescent SMPs offer a cheap and trackable alternative to existing materials for cellular internalisation of proteins, such as the HIV TAT protein and commercial protein delivery agents (e.g. Pierce ${ }^{\mathrm{TM}}$ ).
\end{abstract}

\section{Introduction}

(c) 2018. This manuscript version is made available under the CC-BY-NC-ND 4.0 license http://creativecommons.org/licenses/by-nc-nd/4.0/ 
Silica nanoparticles (SNPs) and mesoporous silica nanoparticles (MSNPs) have been actively studied for a wide range of biomedical applications, 1,2 due to their high inertness, biocompatibility and large specific surface area. ${ }^{1,3}$ These nanoparticles were successfully used for the cellular delivery of nucleic acids, ${ }^{3}$ proteins, ${ }^{4}$ drugs against various types of diseases ${ }^{5}$ and imaging agents, ${ }^{6}$ etc. However, there is general concern about the acute and/or chronic toxicities, as well as the environmental impact caused by nanoparticles. ${ }^{7,} 8$ Indeed, despite great effort in recent decades of the development of biomedical applications of nanoparticles, only a few therapeutic nano-formulations have been approved by the US Food and Drug Administration (FDA).$^{9}$ Therefore, there is a justified rationale for the study and development of biomedical delivery platforms based on larger particles. ${ }^{10-13}$ This general interest resulted in mesoporous silica microparticles (MSMPs), which also recently became a subject of intensive studies in the context of biomedical applications. ${ }^{14-19}$ Surprisingly, conventional silica mesoparticles (SMPs) were studied in this context to a far lesser extent with only a handful of reports for amorphous silica mesoparticles. ${ }^{10-13,20,21}$ These reports nevertheless suggested that SMPs may not only internalise in mammalian cells, but that they may also be less cytotoxic than corresponding nanoparticles. ${ }^{10-13,} 20$ In contrast, polymer particles of sub-micron sizes, which are both biodegradable and non-biodegradable, are well established in the cellular delivery of biological active cargos. ${ }^{22-31}$ Interestingly, it was noticed that both SMPs and polymer particles with the sizes of $500+\mathrm{nm}$ tend not to localise in lysosomes, which are the organelles responsible for digestion and removal of wastes. ${ }^{20,32}$ Such behaviour of these mesoparticles makes them particularly interesting for their application as cellular delivery vehicles, since the biological cargo delivered by the particles is less likely to breakdown within the cells before the cargo serves its purpose.

In order to easily observe the cellular internalisation of particles by conventional methods (e.g. by confocal microscopy), they are typically surface-modified by fluorescent dyes via a chemical process that usually includes at least two studies: 1) surface functionalisation and 2) attachment of a luminescent tag. If the particles are also required to deliver a biologically active cargo, further stages of material modification are required, such as the loading or the attachment of the biological cargo via covalent bonding.

During our recent studies to develop luminescent materials that lack the drawbacks of commodity organic dyes such as poor photostability and self-quenching, we have identified the highly photoluminescent material, $\left(\mathrm{Bu}_{4} \mathrm{~N}\right)_{2}\left[\mathrm{Mo}_{6} \mathrm{I}_{8}\left(\mathrm{NO}_{3}\right)\right]$ (Fig. S1), as a particularly handy precursor for a range of luminescent materials. ${ }^{33-37}$ Specifically, we showed that red emitting mono-disperse SNPs and SMPs that have sizes of $50 \mathrm{~nm}$ and $500 \mathrm{~nm}$, respectively, can be easily prepared via slightly modified Stöber process in a one-step reaction. ${ }^{35}$ In this process tetraethyl orthosilicate (TEOS) is hydrolysed by ammonia in the presence of the cluster. Using this (C) 2018. This manuscript version is made available under the CC-BY-NC-ND 4.0 license http://creativecommons.org/licenses/by-nc-nd/4.0/ 
process, cluster cores $\left\{\mathrm{Mo}_{6} \mathrm{I}_{8}\right\}^{4+}$ that luminesce have been incorporated into silica matrices. The molybdenum cluster doped SNPs were shown to be internalised into the larynx carcinoma (Hep2) cells. The molybdenum cluster were also shown to have low cytotoxicity in darkness, yet have significant photo-induced cytotoxicity upon UV/blue light irradiation. ${ }^{34}$

Since the potentials of SMPs in biomedical applications are generally not studied in detail (if studied at all), we evaluate here the toxicity of SMPs in the dark and their photo-induced toxicity, the cellular internalisation kinetics and the capability of the above red emitting SMPs to act as cellular delivery vehicles using, for the sake of comparison, the same culture line, i.e. Hep2. Importantly, we demonstrate that molybdenum cluster doped SMPs can be successfully applied to protein transductions (i.e. internalisation of proteins into cells, from the external environment), where Green Fluorescent Protein (GFP) was used as a model protein.

\section{Experimental Section}

\section{Materials}

All reagents and solvents were purchased from Alfa Aeser, Sigma Aldrich or Fluka and were used as received without further purification. $\left(\mathrm{Bu}_{4} \mathrm{~N}\right)_{2}\left[\left\{\mathrm{Mo}_{6} \mathrm{I}_{8}\right\}\left(\mathrm{NO}_{3}\right)_{6}\right]$ was prepared according to the described procedures. ${ }^{33}$ The human larynx carcinoma cell line (Hep-2) was purchased from the State Research Center of Virology and Biotechnology VECTOR (Russia) and cultured in Eagle's Minimum Essential Medium (EMEM, pH = 7.4) supplemented with a $10 \%$ fetal bovine serum under a humidified atmosphere $\left(5 \% \mathrm{CO}_{2}\right.$ and $95 \%$ air $)$ at $37^{\circ} \mathrm{C}$.

\section{Synthesis of $\left\{\mathrm{Mo6}_{1} \mathrm{I}_{8}\right\}^{0.01} @ \mathrm{SiO}_{2}$ mesoparticles}

Mesoparticles $\left\{\mathrm{Mo}_{6} \mathrm{I}_{8}\right\}^{0.01} @ \mathrm{SiO}_{2}$ with average particle sizes of 500 nm were synthesised according to the previously reported method. ${ }^{35}$ In general, $6 \mathrm{~mL}$ of an acetone solution containing the cluster complex $\left(\mathrm{Bu}_{4} \mathrm{~N}\right)_{2}\left[\left\{\mathrm{Mo}_{6} \mathrm{I}_{8}\right\}\left(\mathrm{NO}_{3}\right)_{6}\right](1.35 \mathrm{mg})$ was placed in a $10 \mathrm{~mL}$ vial. TEOS $(0.5 \mathrm{~mL}), \mathrm{H}_{2} \mathrm{O}(0.75 \mathrm{~mL})$ and $25 \%$ aqueous ammonia solution $(0.5 \mathrm{~mL})$ were added to the vial, while stirring vigorously. The vial was capped and stirred for $12 \mathrm{~h}$ at room temperature. The yellow solution obtained was centrifuged at $7000 \mathrm{rpm}$ for $10 \mathrm{~min}$, washed by several sonication/centrifugation cycles (five times with acetone and five times with water) and finally dried at $60{ }^{\circ} \mathrm{C}$ in air. Neat SMPs were obtained following a similar procedure but without the cluster. The mean particle size was assessed by TEM (Libra 120, Zeiss) and they were similar to values that were reported earlier, ${ }^{35}$ i.e. $\sim 500 \mathrm{~nm}$.

\section{Surface functionalisation of $\left\{\mathrm{Mo6}_{8} \mathrm{I}^{0.01} @ \mathrm{SiO}_{2}\right.$ by glycidyl-groups (glycidyl- $\left.\left\{\mathrm{Mo}_{6} \mathrm{I}_{8}\right\}^{0.01} @ \mathrm{SiO}_{2}\right)$}

50 mg of powdered $\left\{\mathrm{Mo}_{6} \mathrm{I}_{8}\right\}^{0.01} @ \mathrm{SiO}_{2}$ was dispersed in $2.5 \mathrm{~mL}$ of hexane by sonication for 30 min. $0.0075 \mathrm{~mL}$ of $\mathrm{Et}_{3} \mathrm{~N}$ and $0.05 \mathrm{~mL}$ of (3-glycidyloxypropyl)trimethoxysilane were then added to the dispersion and the resultant mixture was heated at $55{ }^{\circ} \mathrm{C}$ for $3.5 \mathrm{~h}$ under gentle stirring.

(C) 2018. This manuscript version is made available under the CC-BY-NC-ND 4.0 license http://creativecommons.org/licenses/by-nc-nd/4.0/ 
The product of the reaction, i.e. functionalised SMPs were then separated by centrifugation at $7000 \mathrm{rpm}$ for $10 \mathrm{~min}$ and washed five times with hexane and one time with acetone by sonication/centrifugation cycles and finally dried at ambient conditions.

\section{Conjugation of glycidyl- $\left\{\mathrm{Mo}_{6} \mathrm{I}_{8}\right\}^{0.01} @ \mathrm{SiO}_{2}$ with Green Fluorescent Protein (\{Mo6 $\left.\left.\mathrm{I}_{8}\right\}^{0.01} @ \mathrm{SiO}_{2}-\mathrm{GFP}\right)$}

10 mg of glycidyl- $\left\{\mathrm{Mo}_{6} \mathrm{I}_{8}\right\}^{0.01} @ \mathrm{SiO}_{2}$ was washed twice with $5 \mathrm{~mL}$ of buffer solution $(0.1 \mathrm{M}$ $\mathrm{NaCl}$ ) and resuspended in $1 \mathrm{~mL}$ of the coupling buffer $\left(\mathrm{Na}_{2} \mathrm{CO}_{3}\right.$ and $\mathrm{NaHCO}_{3}$ in the concentrations $5.8 \mathrm{mg} \cdot \mathrm{mL}^{-1}$ and $3.8 \mathrm{mg} \cdot \mathrm{mL}^{-1}$, respectively, giving a final $\mathrm{pH}=10$ ). $30 \mu \mathrm{L}$ of GFP (10 mg. $\left.\mathrm{mL}^{-1}\right)$ mixed with $1 \mathrm{~mL}$ of the coupling buffer was added to the dispersion of SMPs and gently stirred for $24 \mathrm{~h}$. Thereafter, the resultant dispersion was washed with $5 \mathrm{~mL}$ of buffer solution, resuspended in $2 \mathrm{~mL}$ of the quenching solution (glycine : Triton X-100 : d/d water $=50$ $\mathrm{mg}$ : $0.014 \mathrm{~mL}: 20 \mathrm{~mL}$ ) and mixed gently for $30 \mathrm{~min}$. Finally, the conjugate was washed again with $5 \mathrm{~mL}$ of the buffer solution and resuspended in $1 \mathrm{~mL}$ of storage buffer (Triton X-100 : Phosphate buffered saline (PBS) $=0.023 \mathrm{~mL}: 50 \mathrm{~mL}$ having final $\mathrm{pH}=7.4$ ). The final concentration of the conjugate was $10 \mathrm{mg} \cdot \mathrm{mL}^{-1}$. The experiment was repeated for nonfunctionalised $\left\{\mathrm{Mo}_{6} \mathrm{I}_{8}\right\}^{0.01} @ \mathrm{SiO}_{2}$ to demonstrate the importance of the glycidyl functionalisation for binding of GFP.

\section{MTT-assay}

The effect of neat $\mathrm{SiO}_{2},\left\{\mathrm{Mo}_{6} \mathrm{I}_{8}\right\}^{0.01} @ \mathrm{SiO}_{2}$ and $\left\{\mathrm{Mo}_{6} \mathrm{I}_{8}\right\}^{0.01} @ \mathrm{SiO}_{2}-\mathrm{GFP}$ on the cells metabolic activity was determined using the 3-[4,5-dimethylthiazol-2-yl]-2,5-diphenyltetrazolium bromide (MTT) colourimetric assay. The Hep-2 cells were seeded into 96-well plates at $7 \times 10^{3}$ cells/well in a medium containing SMPs with concentrations from 1.5 to $1500 \mu \mathrm{g} \cdot \mathrm{mL}^{-1}$ and then incubated for $24 \mathrm{~h}$ under $5 \% \mathrm{CO}_{2}$ atmosphere. $10 \mu \mathrm{L}$ of the MTT solution $\left(5 \mathrm{mg} \cdot \mathrm{mL}^{-1}\right)$ was added to each well, and the plates were incubated for a further $4 \mathrm{~h}$. The formazan produced was then dissolved in DMSO $(100 \mu \mathrm{L})$. The optical density of the solutions was measured with a plate reader Multiskan FC (Thermo scientific, USA) at a wavelength of $570 \mathrm{~nm}$. The experiment was repeated on three separate days.

\section{Cellular internalisation assay}

Hep-2 cells were seeded on a 96-well $\mu$-plate (Ibidi GmbH, Germany) at a density of $7 \times 10^{3}$ cells/well and incubated overnight at $37^{\circ} \mathrm{C}$ under $5 \% \mathrm{CO}_{2}$ atmosphere. The medium was then replaced with a fresh medium containing $0.1 \mathrm{mg} \cdot \mathrm{mL}^{-1}$ of $\left\{\mathrm{Mo}_{6} \mathrm{I}_{8}\right\}^{0.01} @ \mathrm{SiO}_{2}$ or $0.02 \mathrm{mg} \cdot \mathrm{mL}^{-1}$ of $\left\{\mathrm{Mo}_{6} \mathrm{I}_{8}\right\}^{0.01} @ \mathrm{SiO}_{2}-\mathrm{GFP}$ or $20 \mu \mathrm{g} \cdot \mathrm{mL}^{-1} \mathrm{GFP}$ and incubated for $18 \mathrm{~h}$. The cells incubated in the absence of the studied agents were used as a control. Finally, the cells were washed twice with PBS, fixed in 4\% paraformaldehyde, and visualised using an IN Cell Analyzer (GE Healthcare, USA). The nuclei of cells were stained with Hoechst 33342 (Thermo Fisher scientific), the cytoskeletons were visualised with Alexa Fluor ${ }^{\mathrm{TM}} 532$ Phalloidin (Sigma Aldrich). A 375 nm 
excitation source was used with a $700 \mathrm{~nm}$ emission filter for visualizing $\left\{\mathrm{Mo}_{6} \mathrm{I}_{8}\right\}^{0.01} @ \mathrm{SiO}_{2}$ particles, 375/488 for Hoechst, 531/554 for Phalloidin and 488/530 for $\left\{\mathrm{Mo}_{6} \mathrm{I}_{8}\right\}^{0.01} @ \mathrm{SiO}_{2}-\mathrm{GFP}$ and GFP.

\section{Cellular uptake kinetics}

Hep-2 cells were seeded in 6-well plates at a density of $3 \times 10^{5}$ cells per well. They were incubated for $24 \mathrm{~h}$ to reach a confluency greater than 50\%. $\left\{\mathrm{Mo}_{6} \mathrm{I}_{8}\right\}^{0.01} @ \mathrm{SiO}_{2}$, $\left\{\mathrm{Mo}_{6} \mathrm{I}_{8}\right\}^{0.01} @ \mathrm{SiO}_{2}-\mathrm{GFP}$ and GFP were diluted in EMEM medium to a final concentration of 0.1 $\mathrm{mg} \cdot \mathrm{mL}^{-1}$ for $\left\{\mathrm{Mo}_{6} \mathrm{I}_{8}\right\}^{0.01} @ \mathrm{SiO}_{2}$ and $0.02 \mathrm{mg} \cdot \mathrm{mL}^{-1}$ for $\left\{\mathrm{Mo}_{6} \mathrm{I}_{8}\right\}^{0.01} @ \mathrm{SiO}_{2}-\mathrm{GFP}$ or $20 \mu \mathrm{g} \cdot \mathrm{mL}^{-1}$ for GFP. The cells were then cultivated with substances in the culture medium for $0 ; 0.25 ; 0.5 ; 2 ; 4$; 8 and 16 hours at $37^{\circ} \mathrm{C}$ under a $5 \% \mathrm{CO}_{2}$ atmosphere. After treatment, the cells were rinsed three times with ice cold phosphate buffered saline (PBS) to remove any unbound materials. The cells were then trypsinizated and resuspended in fresh PBS with 10\% fetal bovine serum. The cell suspensions were analysed using CytoFlexS (Beckman Coulter, USA). A 375 nm excitation source was used with a 695 \pm 40 nm emission filter for $\left\{\mathrm{Mo}_{6} \mathrm{I}_{8}\right\}^{0.01} @ \mathrm{SiO}_{2}$ and $488 \mathrm{~nm}$ excitation source was used with a 530 \pm 30 nm emission filter for $\left\{\mathrm{Mo}_{6} \mathrm{I}_{8}\right\}^{0.01} @ \mathrm{SiO}_{2}-\mathrm{GFP}$ and GFP. Gating was utilised via a negative sample and the data were expressed as percentage of the fluorescent positive cells. The mean fluorescence was obtained from a population of 10000 cells for each of the assays.

\section{Photoinduced cytotoxicity study}

The Hep-2 cells were seeded in 96-well plates at a density of $7 \times 10^{3}$ cells/well and cultured for 24 h. The medium was then replaced with a fresh medium containing $\left\{\mathrm{Mo}_{6} \mathrm{I}_{8}\right\}^{0.01} @ \mathrm{SiO}_{2}$ in concentration of $0.15-0.0046 \mu \mathrm{g} \cdot \mathrm{mL}^{-1}$ and incubated for $24 \mathrm{~h}$ and the cells were then illuminated with $500 \mathrm{~W}$ halogen lamp $\left(\lambda \geq 400 \mathrm{~nm}\right.$ ) for $30 \mathrm{~min}$ to apply a total light dose of $20 \mathrm{~J} \cdot \mathrm{cm}^{-2}$. The cells cultured in the SMP free medium were used as a control. Cell viability was assayed 24 hours after irradiation using MTT-assay. $10 \mu \mathrm{L}$ of the MTT solution $\left(5 \mathrm{mg} \cdot \mathrm{mL}^{-1}\right)$ was added to each well, and the plates were then incubated for $4 \mathrm{~h}$. The resultant formazan was then dissolved in DMSO $(100 \mu \mathrm{L})$. The optical density was measured with a plate reader Multiskan FC (Thermo scientific, USA) at a wavelength of $620 \mathrm{~nm}$. The experiment was repeated on three separate days.

\section{TEM imaging}

The Hep-2 cells were first cultivated as described in the cellular internalisation assay. Thereafter, the cells were collected with $0.5 \%$ trypsin-EDTA and washed with a $0.1 \mathrm{M}$ phosphate buffer three times. The pre-fixation of the cells was performed in glutaraldehyde for 2 hours. The cells were then fixated in $1 \%$ osmium tetraoxide and gradually dehydrated in ethanol. Finally, the cells were gradually infiltrated with Epon. Specimens were cut over a glass knife using an ultramicrotome Leica EM UC7 to get $70 \mathrm{~nm}$ thin sections on copper grids with 200 mesh. The (C) 2018. This manuscript version is made available under the CC-BY-NC-ND 4.0 license http://creativecommons.org/licenses/by-nc-nd/4.0/ 
grids were stained with uranyl acetate and lead citrate. TEM images were taken using LEO 910 transmission electron microscope (ZEISS).

\section{Statistical analysis}

The Mann-Whitney $\mathrm{U}$ test was used to perform the statistical analysis of the unpaired data. $\mathrm{P}$ values of less than 0.01 were considered significant. The data is presented as mean values \pm SEM (standard error of the mean).

\section{Results and Discussion}

\section{Materials Synthesis and Characterization}

Red emitting mesoparticles $\left\{\mathrm{Mo}_{6} \mathrm{I}_{8}\right\}^{0.01} @ \mathrm{SiO}_{2}$, i.e. silica doped by $\left\{\mathrm{Mo}_{6} \mathrm{I}_{8}\right\}^{4+}$ were obtained and characterised by methods reported elsewhere. ${ }^{35}$ To summarise the earlier results, it was found that luminescent cluster units $\left\{\mathrm{Mo}_{6} \mathrm{I}_{8}\right\}^{4+}$ in the particles bond to silica matrices via Mo-O-Si covalent bonds and hydrogen bonds (e.g. $\mathrm{Mo}^{-} \mathrm{OH}_{2} \cdots \mathrm{O}(\mathrm{H})-\mathrm{Si}$ ), which prohibit any cluster leaching. All SMPs are spherical with an approximate size of $500 \mathrm{~nm}$ (Fig. S2). The particles absorb UV and visible wavelengths up to $550 \mathrm{~nm}$ and emit in the region 600-830 $\mathrm{nm}$ with the maximum of emission at $\sim 700 \mathrm{~nm}$. The photoluminescence quantum yield was $0.08 .{ }^{35}$ The particles are also capable of the generation of some singlet oxygen, but at least 4 times less efficiently in comparison to the corresponding SNPs of $50 \mathrm{~nm}$, due to the smaller specific surface area of the larger particles. These properties (emission in the red region combines with relatively poor ability to generate singlet oxygen) make these SMPs attractive for biolabeling and bioimaging applications as well as a traceable cellular delivery vehicle for a biological cargo.

Protein transduction is an emerging technology that can be used to study the functions of proteins and enzymes as well as to deliver therapeutic proteins. ${ }^{29,} 38,39$ It can be performed either when a protein is chemically bonded to the delivery vehicle or when it is not bonded (i.e loaded) onto or within the vehicle. Both modes of use have their own advantages and disadvantages depending on their application. ${ }^{40}$ Specifically, in the context of in vivo applications, rigid linkage between the carrier and the protein can be extremely important to avoid cargo leakage. Therefore, to evaluate the potential of the luminescent SMPs in this application we have functionalised the surface of the particles $\left\{\mathrm{Mo}_{6} \mathrm{I}_{8}\right\}^{0.01} @ \mathrm{SiO}_{2}$ with epoxy groups using (3glycidyloxypropyl)trimethoxysilane, which allows consequent conjugation of silica with proteins. ${ }^{41,42}$ Glycidyl-functionalised $\left\{\mathrm{Mo}_{6} \mathrm{I}_{8}\right\}^{0.01} @ \mathrm{SiO}_{2}$ SMPs were then conjugated with Green Fluorescent Protein (GFP) to produce stable suspensions of $\left\{\mathrm{Mo}_{6} \mathrm{I}_{8}\right\}^{0.01} @ \mathrm{SiO}_{2}-\mathrm{GFP}$ particles in an aqueous medium (Scheme 1). GFP is indeed a convenient model protein for this study, firstly, because its' emission does not interfere with that emanating from the clusters and secondly in its' free form, GFP does not effectively internalise into cells. ${ }^{43-45}$

(C) 2018. This manuscript version is made available under the CC-BY-NC-ND 4.0 license http://creativecommons.org/licenses/by-nc-nd/4.0/ 


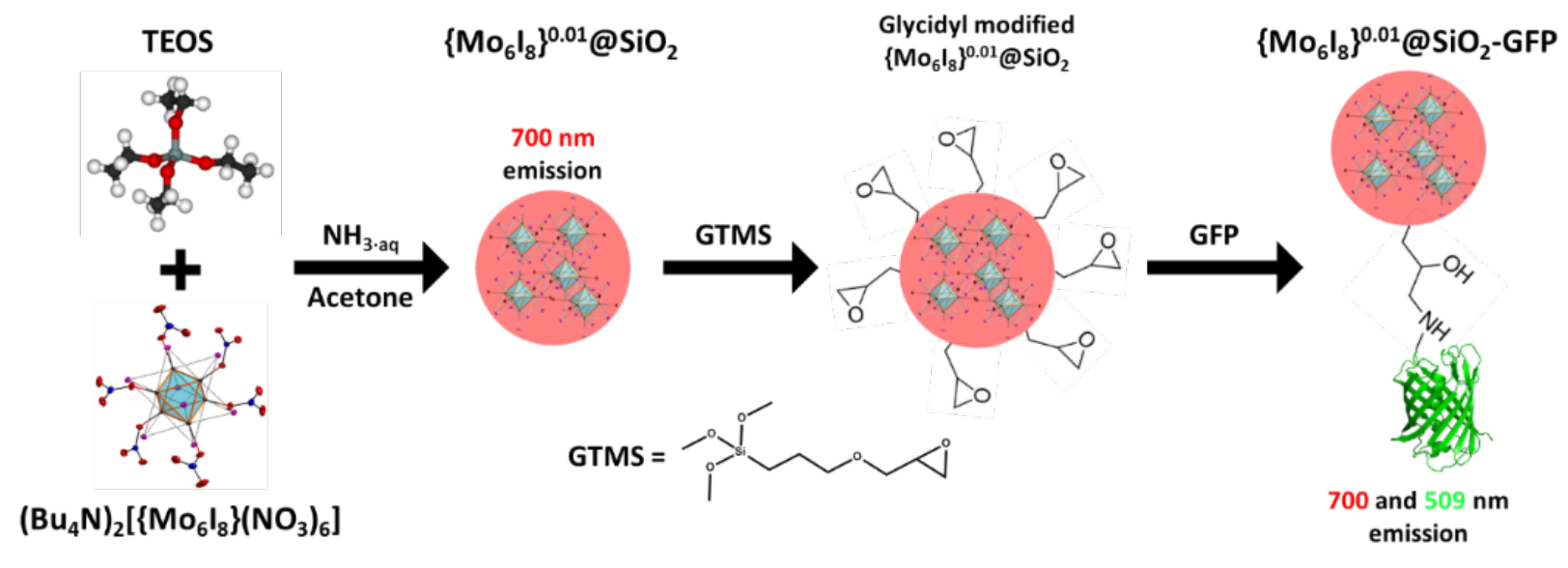

Scheme 1. The synthetic procedure of $\left\{\mathrm{Mo}_{6} \mathrm{I}_{8}\right\}^{0.01} @ \mathrm{SiO}_{2}-\mathrm{GFP}$.

It is well-known that proteins are capable of adherence or adsorption onto the surface of silica due to non-covalent interactions. ${ }^{46,} 47$ Therefore, it is crucial to demonstrate that the glycidyl modification of silica is important for protein labelling. $\left\{\mathrm{Mo}_{6} \mathrm{I}_{8}\right\}^{0.01} @ \mathrm{SiO}_{2}$, non-functionalised $\left\{\mathrm{Mo}_{6} \mathrm{I}_{8}\right\}^{0.01} @ \mathrm{SiO}_{2}$ treated by GFP and the conjugated material $\left\{\mathrm{Mo}_{6} \mathrm{I}_{8}\right\}^{0.01} @ \mathrm{SiO}_{2}-\mathrm{GFP}$ were analysed by flow cytometry (FACS). According to our data, all of the particles had the same intensity of red emission, i.e. no damage to the molybdenum cluster had occurred during subsequent reactions (Fig. 1A). Moreover, $\left\{\mathrm{Mo}_{6} \mathrm{I}_{8}\right\}^{0.01} @ \mathrm{SiO}_{2}-\mathrm{GFP}$ particles are at least 4.5 times more emissive in the green wavelength region than the non-functionalised $\left\{\mathrm{Mo}_{6} \mathrm{I}_{8}\right\}^{0.01} @ \mathrm{SiO}_{2}$ particles treated by GFP (Fig. 1B, Fig. S3). Thus, the glycidyl surface modification of $\left\{\mathrm{Mo}_{6} \mathrm{I}_{8}\right\}^{0.01} @ \mathrm{SiO}_{2}$ does indeed significantly increase the ability of the particles to bind to proteins.
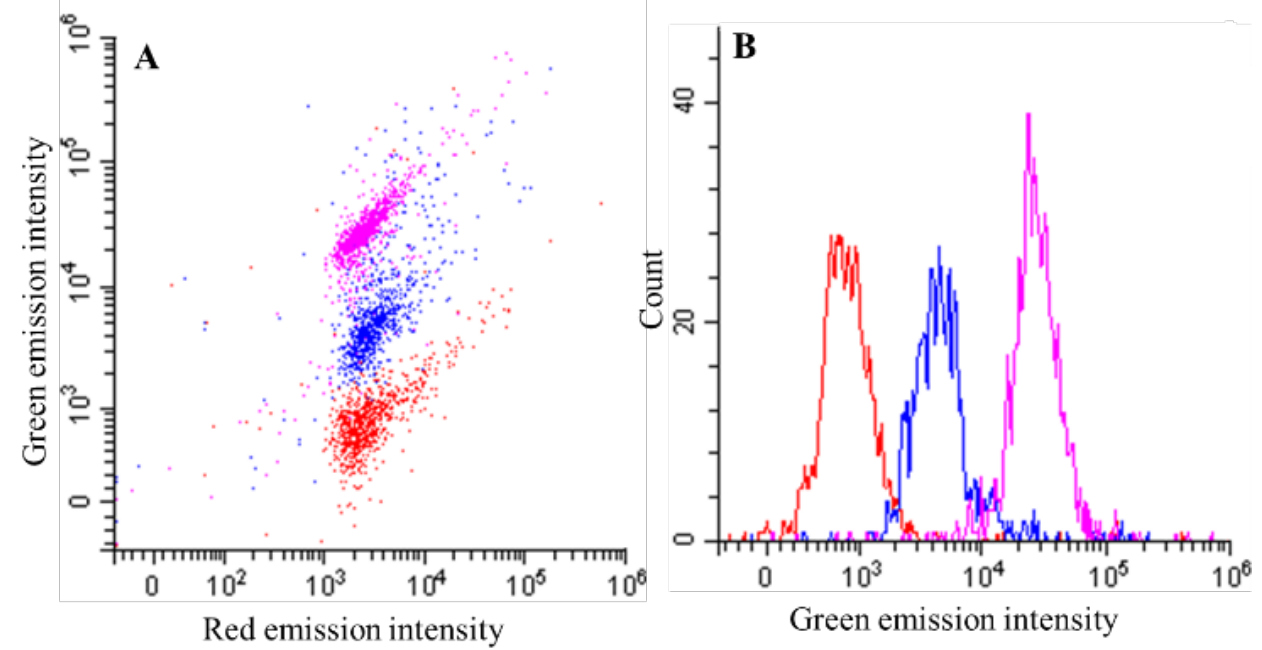

Fig. 1. FACS data for $\left\{\mathrm{Mo}_{6} \mathrm{I}_{8}\right\}^{0.01} @ \mathrm{SiO}_{2}$ (red), non-functionalised $\left\{\mathrm{Mo}_{6} \mathrm{I}_{8}\right\}^{0.01} @ \mathrm{SiO}_{2}$ treated by GFP (blue) and the conjugated material $\left\{\mathrm{Mo}_{6} \mathrm{I}_{8}\right\}^{0.01} @ \mathrm{SiO}_{2}$-GFP (magenta). A) Red and green emission

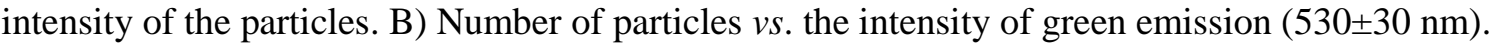

\section{Cellular uptake and localisation of $\left\{\mathrm{Mo}_{6} \mathrm{I}_{8}\right\}^{0.01} @ \mathrm{SiO}_{2}$ mesoparticles}

The cellular uptake of SNPs is thoroughly documented in the literature, while studies on the (C) 2018. This manuscript version is made available under the CC-BY-NC-ND 4.0 license http://creativecommons.org/licenses/by-nc-nd/4.0/ 
cellular internalisation and localisation of silica particles of above $200 \mathrm{~nm}$ are quite rare, ${ }^{20,48-50}$ despite the fact that SMPs were generally shown to be less cytotoxic in comparison with nanoparticles. $\underline{10-13}$, 20 Here, the uptake of GFP, $\left\{\mathrm{Mo}_{6} \mathrm{I}_{8}\right\}^{0.01} @ \mathrm{SiO}_{2}$ and $\left\{\mathrm{Mo}_{6} \mathrm{I}_{8}\right\}^{0.01} @ \mathrm{SiO}_{2}-\mathrm{GFP}$ by Hep-2 cells was analysed using fluorescent microscopy, flow cytometry (FACS) and Transmission Electron Microscopy (TEM).

Characteristic fluorescent microscope images of Hep-2 cells taken after cultivation with GFP and the SMPs are presented in Figure 2. These images allow us to draw several important conclusions. Firstly, both $\left\{\mathrm{Mo}_{6} \mathrm{I}_{8}\right\}^{0.01} @ \mathrm{SiO}_{2}$ and $\left\{\mathrm{Mo}_{6} \mathrm{I}_{8}\right\}^{0.01} @ \mathrm{SiO}_{2}-\mathrm{GFP}$ internalise into Hep-2 cells, as can be observed in the red emissions, which are localised throughout the whole cytoplasm volume of the cells. Secondly, GFP itself does not penetrate into the cells in accordance with other studies. ${ }^{43-45}$ Finally, green emissions are observed that coincide with the location of the red emissions of the SMPs. The green emissions are associated with GFP within the cells treated by $\left\{\mathrm{Mo}_{6} \mathrm{I}_{8}\right\}^{0.01} @ \mathrm{SiO}_{2}-\mathrm{GFP}$, which signifies that GFP does penetrate as a part of the conjugate with the SMPs. 


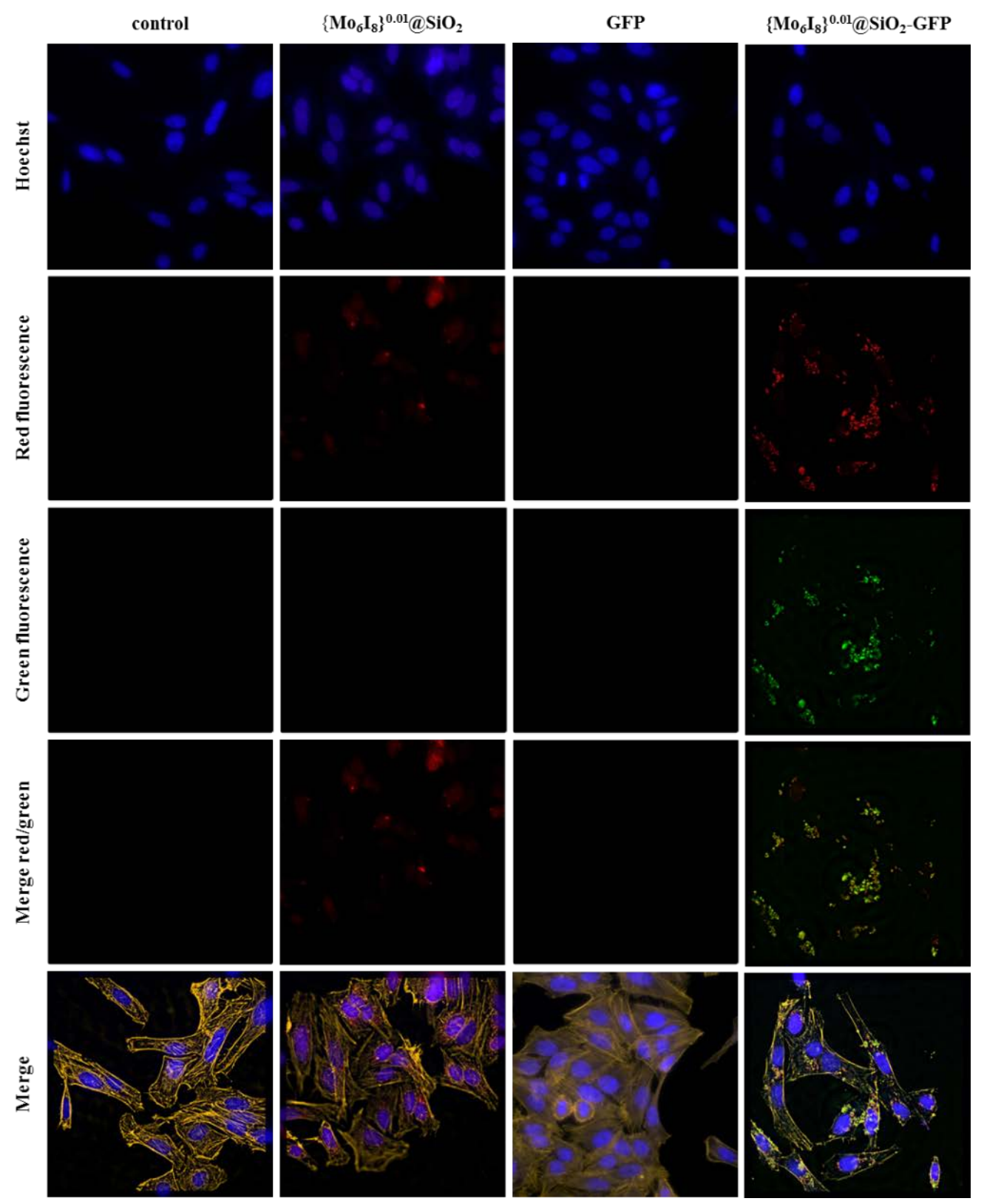

Fig. 2. Cellular uptake of $\left\{\mathrm{Mo}_{6} \mathrm{I}_{8}\right\}^{0.01} @ \mathrm{SiO}_{2},\left\{\mathrm{Mo}_{6} \mathrm{I}_{8}\right\}^{0.01} @ \mathrm{SiO}_{2}-\mathrm{GFP}$ and GFP by fluorescent microscopy. The cell nuclei were labelled with Hoechst 33342 (blue), the cytoskeleton with Phalloidin (orange), GFP - green fluorescence protein (green) and theluminescent particles (red). The control images are for cells incubated in the absence of the analytes.

FACS studies further support the above conclusions of the successful internalisation of both $\left\{\mathrm{Mo}_{6} \mathrm{I}_{8}\right\}^{0.01} @ \mathrm{SiO}_{2}$ and $\left\{\mathrm{Mo}_{6} \mathrm{I}_{8}\right\}^{0.01} @ \mathrm{SiO}_{2}-\mathrm{GFP}$. Indeed, the cells incubated with both types of SMPs showed significant increase of luminescence in comparison with the negative control (untreated cells), while the cell incubated with native GFP did not show any noticeable increase in luminescence (Fig. 3A).

The kinetics of internalisation - indicated by the percentage of luminescent Hep-2 cells vs. time (Fig. 3B) shows that the internalisation of the particles $\left\{\mathrm{Mo}_{6} \mathrm{I}_{8}\right\}^{0.01} @ \mathrm{SiO}_{2}-\mathrm{GFP}$ is the most intensive within the first hour and plateaus after 4 hours, while it is noticeably slower for $\left\{\mathrm{Mo}_{6} \mathrm{I}_{8}\right\}^{0.01} @ \mathrm{SiO}_{2}$ even though the cells were incubated at a higher concentration of particles. (C) 2018. This manuscript version is made available under the CC-BY-NC-ND 4.0 license http://creativecommons.org/licenses/by-nc-nd/4.0/ 
Some discrepancy of the uptake kinetics between $\left\{\mathrm{Mo}_{6} \mathrm{I}_{8}\right\}^{0.01} @ \mathrm{SiO}_{2}-\mathrm{GFP}$ and $\left\{\mathrm{Mo}_{6} \mathrm{I}_{8}\right\}^{0.01} @ \mathrm{SiO}_{2}$ are likely due to both the difference in the surface coating of the particles and the agglomeration of the particles that is less significant in the case of $\left\{\mathrm{Mo}_{6} \mathrm{I}_{8}\right\}^{0.01} @ \mathrm{SiO}_{2}-\mathrm{GFP}$ (Fig. S3, S4).
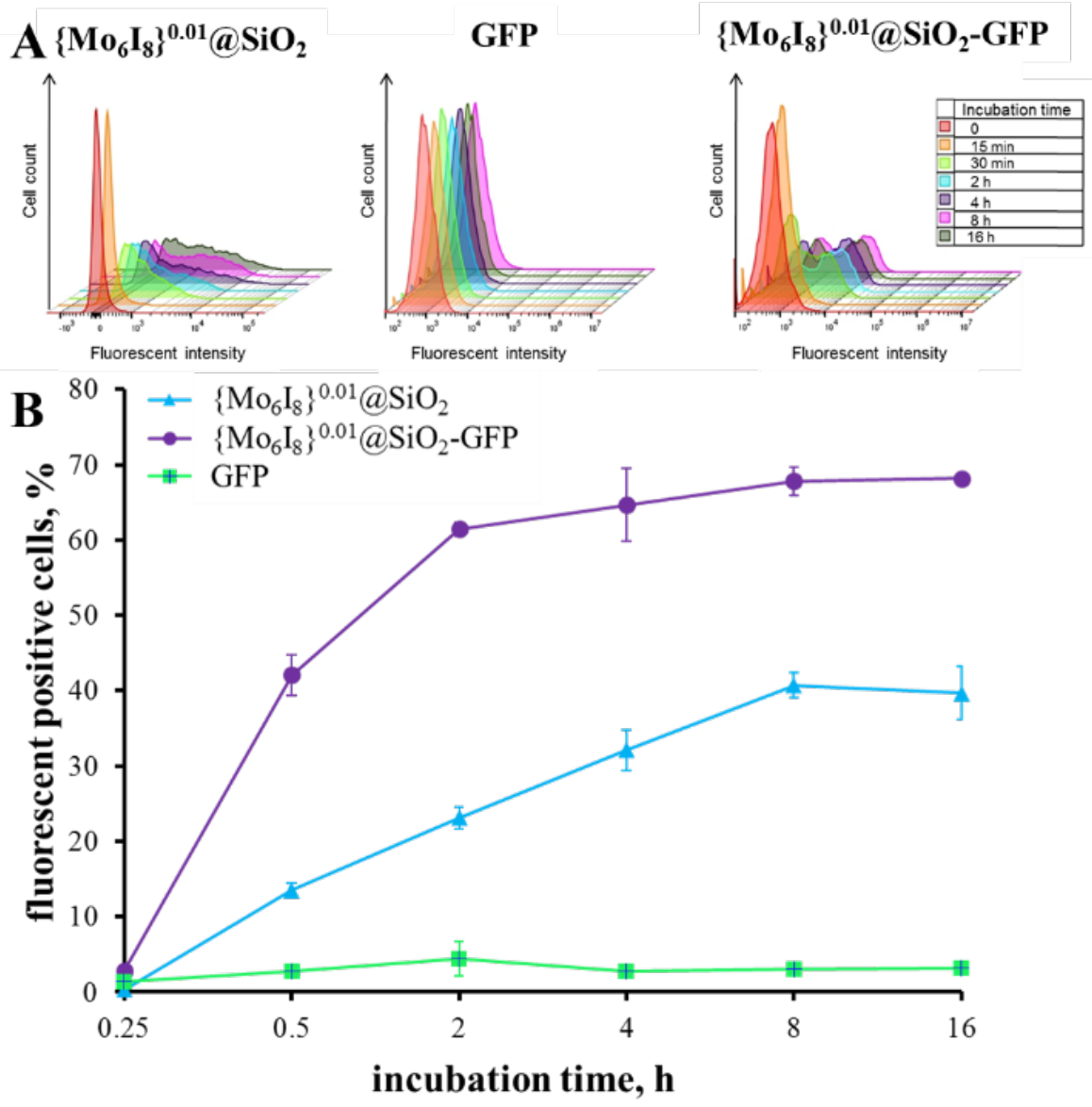

Fig. 3. FACS assay results. A) Hep-2 Cells sorting depending on the time of incubation with $0.1 \mathrm{mg} \mathrm{mL}^{-1}$ of $\left\{\mathrm{Mo}_{6} \mathrm{I}_{8}\right\}^{0.01} @ \mathrm{SiO}_{2}\left(\lambda_{\text {ex }}=488 \mathrm{~nm}, \lambda_{\text {em }}=695 \pm 40 \mathrm{~nm}\right), 0.02 \mathrm{mg} \mathrm{mL}{ }^{-1}$ of $\left\{\mathrm{Mo}_{6} \mathrm{I}_{8}\right\}^{0.01} @ \mathrm{SiO}_{2}-\mathrm{GFP}$ or 20 $\mu \mathrm{g} \cdot \mathrm{mL}^{-1}$ GFP $\left(\lambda_{\mathrm{ex}}=488 \mathrm{~nm}, \lambda_{\mathrm{em}}=530 \pm 30 \mathrm{~nm}\right)$; B) Percentage of luminescent Hep-2 cells vs. incubation times.

Unlike nanoparticles, both pinocytosis and phagocytosis are the most expected mechanisms of internalisation for mesoparticles. ${ }^{51,} 52$ TEM images (Fig. 4 and S5) of the cells after internalisation with $\left\{\mathrm{Mo}_{6} \mathrm{I}_{8}\right\}^{0.01} @ \mathrm{SiO}_{2}$ and $\left\{\mathrm{Mo}_{6} \mathrm{I}_{8}\right\}^{0.01} @ \mathrm{SiO}_{2}-\mathrm{GFP}$ demonstrated that regardless of whether they had a cargo or not, the particles were localised inside of the single-layer vesicles located in the cellular cytoplasm. Moreover, no extracellular fluid was observed in the vesicles surrounding the particles, i.e. the vesicles engulfed the particles very closely (Fig. 4B and 4D). This observation indicates that the most likely mechanism of cellular internalisation for the SMPs is phagocytosis. ${ }^{53,54}$ We have also observed the particles within early endosomes (Fig. 4C), while particles in lysosomes (or, indeed, fusion of phagosomes with lysosomes) were not observed. This observation is in the agreement with the earlier work on size-dependent silica particles internalisation in cervical cancer cells (HeLa), where no SMPs were found within the lysosomes. ${ }^{20}$ The high inertness of the SMPs (see below) is the most likely reason why the (c) 2018. This manuscript version is made available under the CC-BY-NC-ND 4.0 license http://creativecommons.org/licenses/by-nc-nd/4.0/ 
particle containing phagosomes fail to fuse with lysosomes. Such a fate of the particles within the cells suggests that they can be present in the cellular cytoplasm for long time without any active excretion and any significant damage to the cargo they bear.

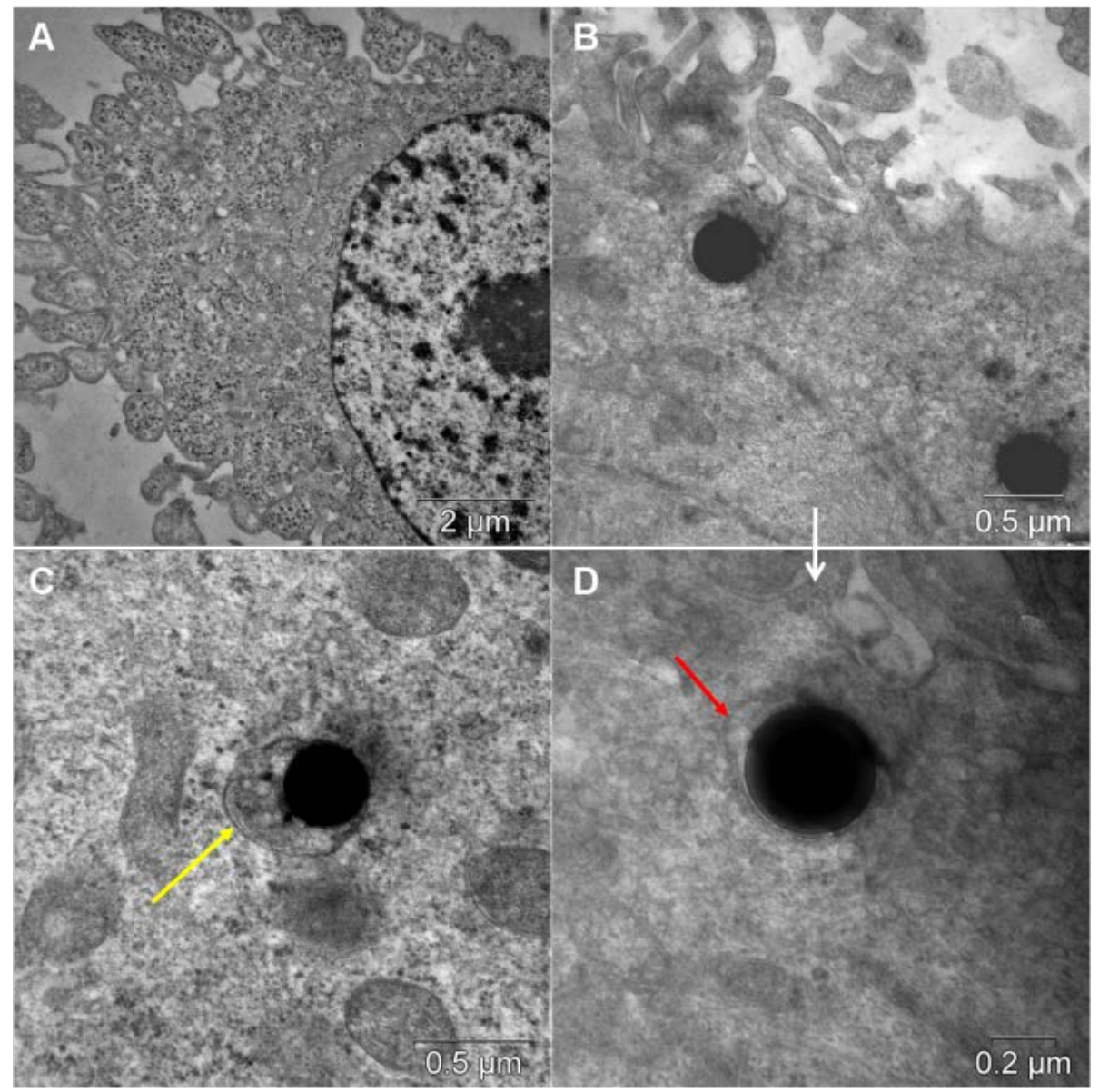

Fig. 4. Reprisentative TEM images of Hep-2 cells: A) Control cells. B-D) The cells after 12 hours of incubation with SMPs. The red arrow shows SMPs engulfed in a single-layer vesicle. The yellow arrow shows SMPs in an early endosome.

\section{Cytotoxicity of $\left\{\mathrm{Mo}_{6} \mathrm{I}_{8}\right\}^{0.01} @ \mathrm{SiO}_{2}$ and $\left\{\mathrm{Mo}_{6} \mathrm{I}_{8}\right\}^{0.01} @ \mathrm{SiO}_{2}-\mathrm{GFP}$}

The standard MTT-assay technique was used to evaluate the cytotoxicity of the SMPs samples on the Hep-2 cells. The assay was undertaken in the presence of serum for the sake of comparison with the related earlier study on SNPs. ${ }^{34}$ Note that several studies indicate that neat silica particles were found to be more toxic in the absence of serum. ${ }^{20,55-57}$ The results of MTT assay are presented in Figure 5. For comparison, the MTT assay was also undertaken for neat SMPs and particles with varied loading of the cluster (Fig. S6). The half-maximal inhibitory concentrations $\left(\mathrm{IC}_{50}\right)$ values for the SMPs are summarised in Table 1 . The rate of the metabolically active cells was determined against the negative control. According to data obtained, $\mathrm{SiO}_{2}$ and cluster-doped particles have similar values of cellular toxicity. Namely, in the concentration range from 0.01 to $0.18 \mathrm{mg} \cdot \mathrm{mL}^{-1}$, the SMPs did not affect viability of the cells, while at higher concentrations, these particles lead to reduced cellular viability and proliferation.

(C) 2018. This manuscript version is made available under the CC-BY-NC-ND 4.0 license http://creativecommons.org/licenses/by-nc-nd/4.0/ 
This toxicity pattern is very similar to those found for related cluster-doped SNPs, which have a particle size of $50 \mathrm{~nm} .{ }^{34}$ The usable concentrations for practical biomedical applications for either type of the materials are thus recommended to not exceed $0.18 \mathrm{mg} \cdot \mathrm{mL}^{-1}$.

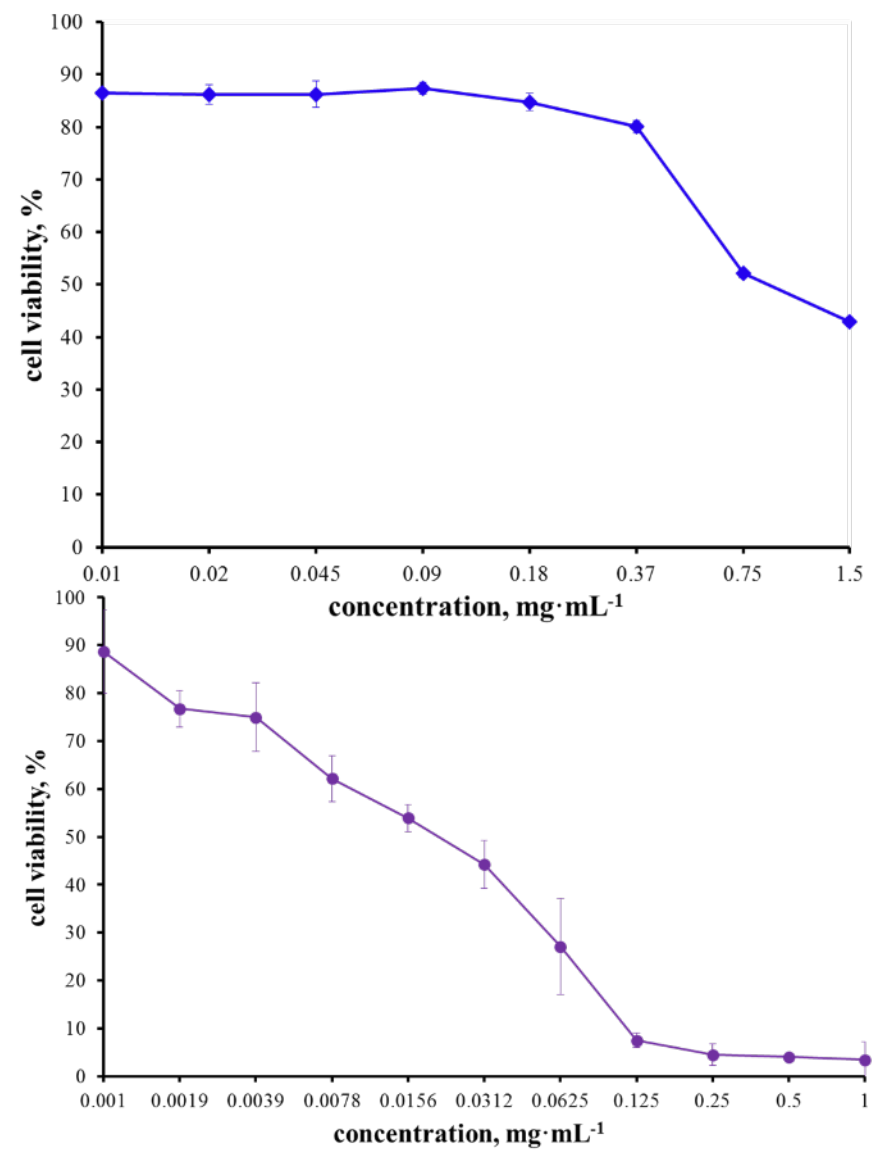

Fig. 5. Cytotoxicity of $\left\{\mathrm{Mo}_{6} \mathrm{I}_{8}\right\}^{0.01} @ \mathrm{SiO}_{2} \mathrm{SMPs}$ for $\mathrm{Hep}-2$ cells (up) and $\left\{\mathrm{Mo}_{6} \mathrm{I}_{8}\right\}^{0.01} @ \mathrm{SiO}_{2}-\mathrm{GFP}$ conjugate (bottom).

$\left\{\mathrm{Mo}_{6} \mathrm{I}_{8}\right\}^{0.01} @ \mathrm{SiO}_{2}-\mathrm{GFP}$ demonstrated significantly higher cellular toxicity: the determined $\mathrm{IC}_{50}$ value was approximately 50 times lower than that for non-conjugated material. This result is in the agreement with other studies, for example review ${ }^{58}$ summarises various mechanisms of GFP cytotoxicity. The noticeable increased dark toxicity of GFP conjugated material observation is not only the additional evidence of successful internalisation of GFP but also demonstrates that GFP remains active within the cells

Table 1. $\mathrm{IC}_{50}$ values for the SMPs.

\begin{tabular}{ccccccc}
\hline & $\mathrm{SiO}_{2}$ & $\multicolumn{4}{c}{\mathrm{Mo}_{6} \mathrm{I}_{8}}^{\mathrm{n}} @ \mathrm{SiO}_{2}$ & \multirow{2}{*}{ noo $\left._{6} \mathrm{I}_{8}\right\}^{0.01} @ \mathrm{SiO}_{2-}$} \\
\cline { 3 - 5 } & $\mathrm{n}=0.0005$ & $\mathrm{n}=0.001$ & $\mathrm{n}=0.005$ & $\mathrm{n}=0.01$ & GFP \\
\hline $\begin{array}{c}\mathrm{IC}_{50}, \\
\left(\mathrm{mg} \cdot \mathrm{mL}^{-1}\right)\end{array}$ & $1.27 \pm 0.03$ & $0.86 \pm 0.01$ & $0.92 \pm 0.01$ & $1.06 \pm 0.02$ & $0.94 \pm 0.01$ & $0.022 \pm 0.002$ \\
\hline
\end{tabular}

\section{Evaluation of the photo-induced cytotoxic effect on Hep-2 cells}

We have earlier demonstrated that both molybdenum cluster doped SNPs and SMPs are capable

(C) 2018. This manuscript version is made available under the CC-BY-NC-ND 4.0 license http://creativecommons.org/licenses/by-nc-nd/4.0/ 
of singlet oxygen generation. ${ }^{34,} 35$ Moreover we have shown that this ability of the SNPs causes significant photo-induced cytotoxicity. Since the above results confirm that molybdenum clusterdoped SMPs, despite having larger sizes, successfully penetrate into the Hep-2 cells and tend to localise within the whole volume of cytoplasm, it is vital to evaluate the photo-induced cellular toxicity of the material associated with the presence of the cluster.

The MTT assay technique was then used to determine the viability of Hep-2 cells cultivated with $\left\{\mathrm{Mo}_{6} \mathrm{I}_{8}\right\}^{0.01} @ \mathrm{SiO}_{2}$ in the non-toxic range $0.0046-0.15 \mathrm{mg} \mathrm{mL}^{-1}$ for $24 \mathrm{~h}$ and irradiated for 30 min with $\lambda>400 \mathrm{~nm}$. Our data show that $\left\{\mathrm{Mo}_{6} \mathrm{I}_{8}\right\}^{0.01} @ \mathrm{SiO}_{2}$ demonstrate slightly increased photoinduced cytotoxicity in comparison with neat SMPs, which were non-toxic under radiation within the whole range of the studies concentrations (Fig. 6). However, even at the highest studied concentration of $\left\{\mathrm{Mo}_{6} \mathrm{I}_{8}\right\}^{0.01} @ \mathrm{SiO}_{2}, 0.15 \mathrm{mg} \cdot \mathrm{mL}^{-1}$, the percentage of the living cells after photoirradiation for 30 min was more than $80 \%$. For comparison, the percentage of the living Hep-2 cells incubated with $\left\{\mathrm{Mo}_{6} \mathrm{I}_{8}\right\}^{0.01} @ \mathrm{SiO}_{2}$ nanoparticles at the same concentration after the same time of irradiation was found to be $20 \% .^{34}$

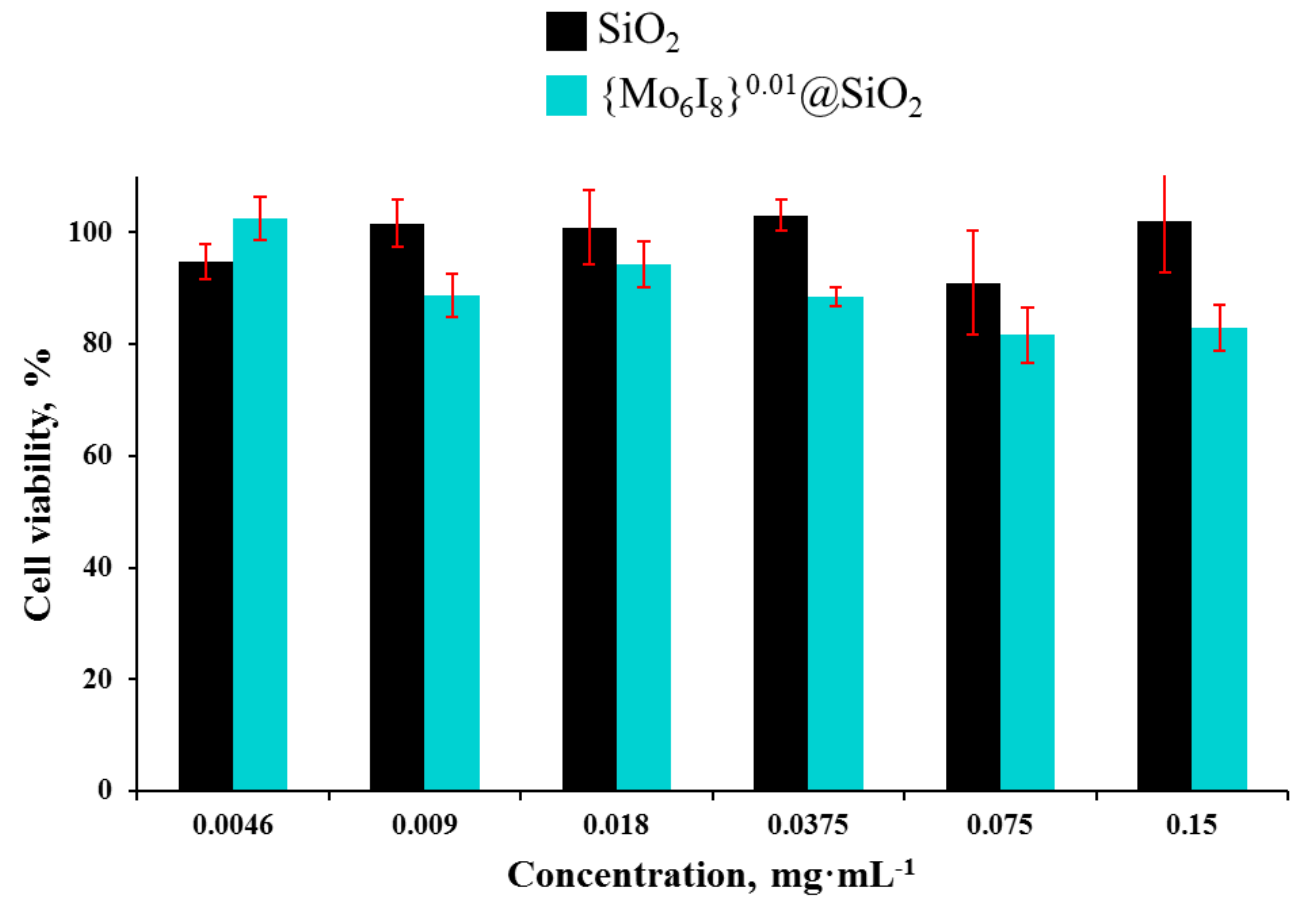

Fig. 6. Photoinduced cytotoxicity of $\left\{\mathrm{Mo}_{6} \mathrm{I}_{8}\right\}^{0.01} @ \mathrm{SiO}_{2}$ on Hep-2 cells.

Overall the photo-induced cytotoxicity of SMPs is only slightly higher than that found for other sub-micron size materials doped by $\left\{\mathrm{Mo}_{6} \mathrm{I}_{8}\right\}^{4+}$. For example the survival rate of Hep-2 cells treated by $\left\{\mathrm{Mo}_{6} \mathrm{I}_{8}\right\} @$ MIL-101 was 93\%, ${ }^{59}$ while no photo-induced cytotoxic effect was found for polystyrene-based materials $\left\{\mathrm{Mo}_{6} \mathrm{I}_{8}\right\} @$ PSS. ${ }^{60}$

\section{Conclusions.}

In conclusion, this work demonstrates that SMPs doped by luminescent molybdenum cluster is a highly attractive material for biomedical application, in particular for the bioimaging and biolabeling of cells, as well as for the cellular delivery of biological molecules, such as proteins. (C) 2018. This manuscript version is made available under the CC-BY-NC-ND 4.0 license http://creativecommons.org/licenses/by-nc-nd/4.0/ 
Firstly, this luminescent material is obtained in a one-stage process using inexpensive precursors and no organic surfactants. It does not contain "fragile” organic parts that could be damaged in the consequent reactions of functionalisation or loading with a biological cargo and photoirradiation. Secondly, the material is compatible with well-established methods to functionalise silica. To demonstrate this, we have functionalised the particles with glycidyl groups and subsequently conjugated the particles with GFP protein. Thirdly, the particles themselves have very low levels of both dark and photo-induced cytotoxicity and they can be used in the concentrations up to $0.18 \mathrm{mg} \cdot \mathrm{mL}^{-1}$. Fourthly, the particles were shown to efficiently internalise into Hep-2 cells following phagocytosis and localise within the whole volume of cytoplasm. Notably, the particle loaded phagocytes tend to fuse with early endosomes rather than the lysosomes. The emission from the particles within the cells was intensive enough to be detected by conventional methods, not only by very sensitive FACS method, but also by confocal microscopy. Finally, using GFP we have demonstrated that molybdenum cluster doped SMPs can efficiently deliver a biological cargo into a cell, where the efficiency of the delivery of the cargo can be easily monitored by the emission from the SMPs. Overall, this study demonstrates that sub-micron SMPs produced by conventional surfactant-free Stöber process have a high potential for biomedical applications, in particular in the context of protein delivery. This study should be further supported with further detailed in vitro and in vivo studies to allow this exceptionally cheap material to fully exploit its potential.

\section{Declarations of interest}

None.

\section{Acknowledgements}

This work was supported by the Russian Foundation for Basic Research (grants No. 18-31500235 and 17-03-00140). OE thanks the Royal Society for the research grant RSG\R1\180123 and EPSRC grant (EP/R006393/1). MS is grateful to the the Grant of the President of the Russian Federation [grant number MK 180.2017.3]. The NIIC team thanks Federal Agency for Scientific Organisations for funding. Also, Y. A. Vorotnikov thanks the government of Novosibirsk region for the fellowship for young scientists. We are grateful to the following multi-access centers: "Microscopic analysis of biological objects" (SB RAS), "Proteomics” and "Spectrometric measurements" (Federal Research Center of Fundamental and Translational Medicine, Novosibirsk, Russia) for granting access to the equipment.

\section{Appendix A. Supplementary data}

Supplementary data related to this article can be found at https://doi.org/

\section{References}

1. J. S. Wang, Z. H. Shah, S. F. Zhang and R. W. Lu, Nanoscale, 2014, 6, 4418-4437. doi:10.1039/c3nr06025j

(C) 2018. This manuscript version is made available under the CC-BY-NC-ND 4.0 license http://creativecommons.org/licenses/by-nc-nd/4.0/ 
2. S. Z. Chen, X. H. Hao, X. J. Liang, Q. Zhang, C. M. Zhang, G. Q. Zhou, S. G. Shen, G. Jia and J. C. Zhang, J. Biomed. Nanotechnol., 2016, 12, 1-27. doi:10.1166/jbn.2016.2122

3. W. Z. Cha, R. G. Fan, Y. F. Miao, Y. Zhou, C. L. Qin, X. X. Shan, X. Q. Wan and J. B. Li, Molecules, 2017, 22, 782. doi:10.3390/Molecules22050782

4. M. H. Yu, Z. Y. Gu, T. Ottewell and C. Z. Yu, J. Mater. Chem. B, 2017, 5, 3241-3252. doi:10.1039/c7tb00244k

5. J. Wen, K. Yang, F. Y. Liu, H. J. Li, Y. Q. Xu and S. G. Sun, Chem. Soc. Rev., 2017, 46, 6024-6045. doi:10.1039/c7cs00219j

6. O. S. Wolfbeis, Chem. Soc. Rev., 2015, 44, 4743-4768. doi:10.1039/c4cs00392f

7. M. V. D. Z. Park, W. Annema, A. Salvati, A. Lesniak, A. Elsaesser, C. Barnes, G. McKerr, C. V. Howard, I. Lynch, K. A. Dawson, A. H. Piersma and W. H. de Jong, Toxicol. Appl. Pharm., 2009, 240, 108-116. doi:10.1016/j.taap.2009.07.019

8. D. Napierska, L. C. J. Thomassen, D. Lison, J. A. Martens and P. H. Hoet, Part. Fibre Toxicol., 2010, 7, 39. doi:10.1186/1743-8977-7-39

9. F. Q. Tang, L. L. Li and D. Chen, Adv. Mater., 2012, 24, 1504-1534. doi:10.1002/adma.201104763

10. D. Napierska, L. C. J. Thomassen, V. Rabolli, D. Lison, L. Gonzalez, M. Kirsch-Volders, J. A. Martens and P. H. Hoet, Small, 2009, 5, 846-853. doi:10.1002/smll.200800461

11. H. H. Yuan, F. Gao, Z. G. Zhang, L. D. Miao, R. H. Yu, H. L. Zhao and M. B. Lan, J. Health. Sci., 2010, 56, 632-640. doi:10.1248/Jhs.56.632

12. P. Ariano, P. Zamburlin, A. Gilardino, R. Mortera, B. Onida, M. Tomatis, M. Ghiazza, B. Fubini and D. Lovisolo, Small, 2011, 7, 766-774. doi:10.1002/smll.201002287

13. Y. Li, L. Sun, M. H. Jin, Z. J. Du, X. M. Liu, C. X. Guo, Y. B. Li, P. L. Huang and Z. W. Sun, Toxicol. in Vitro, 2011, 25, 1343-1352. doi:10.1016/j.tiv.2011.05.003

14. J. L. Steinbacher, S. A. Lathrop, K. Cheng, J. M. Hillegass, K. Butnor, R. A. Kauppinen, B. T. Mossman and C. C. Landry, Small, 2010, 6, 2678-2682. doi:10.1002/smll.201001447

15. S. Al-Salam, G. Balhaj, S. Al-Hammadi, M. Sudhadevi, S. Tariq, A. V. Biradar, T. Asefa and A. K. Souid, Toxicol. Sci., 2011, 122, 86-99. doi:10.1093/toxsci/kfr078

16. X. D. Liu, Y. J. Yu, M. Y. Zhao, H. Y. Zhang, Y. Li and G. L. Duan, Food Chem., 2014, 150, 206-212. doi:10.1016/j.foodchem.2013.10.145

17. Y. P. Bi, C. N. Wu, M. Xin, S. Y. Bi, C. X. Yan, J. F. Hao, F. Li and S. Li, Int. J. Pharmaceut., 2016, 500, 77-84. doi:10.1016/j.ijpharm.2016.01.027

18. G. Günal, Ç. Kip, S. E. Öğüt, D. D. Usta, E. Şenlik, G. Kibar and A. Tuncel, Mater. Sci. Eng. C, 2017, 74, 10-20. doi:10.1016/j.msec.2016.12.118

19. D. P. Li, R. X. Yi, J. W. Tian, J. H. Li, B. Y. Yu and J. Qi, Chem. Commun., 2017, 53, 8902-8905. doi:10.1039/c7cc04070a

(C) 2018. This manuscript version is made available under the CC-BY-NC-ND 4.0 license http://creativecommons.org/licenses/by-nc-nd/4.0/ 
20. M. Al-Rawi, S. Diabate and C. Weiss, Arch. Toxicol., 2011, 85, 813-826. doi:10.1007/s00204-010-0642-5

21. P. Decuzzi, B. Godin, T. Tanaka, S. Y. Lee, C. Chiappini, X. Liu and M. Ferrari, J. Control Release, 2010, 141, 320-327. doi:10.1016/j.jconrel.2009.10.014

22. D. T. O'Hagan, M. Singh and J. B. Ulmer, Immunol. Rev., 2004, 199, 191-200. doi:10.1111/j.0105-2896.2004.00153.x

23. J. Siepmann and F. Siepmann, Prog. Coll. Pol. Sci., 2006, 133, 15-21. doi:10.1007/2882_053

24. N. Gennet, L. M. Alexander, R. M. Sanchez-Martin, J. M. Behrendt, A. J. Sutherland, J. M. Brickman, M. Bradley and M. Li, New Biotechnol., 2009, 25, 442-449. doi:10.1016/j.nbt.2009.05.006

25. R. M. Sanchez-Martin, L. Alexander, M. Muzerelle, J. M. Cardenas-Maestre, A. Tsakiridis, J. M. Brickman and M. Bradley, Chembiochem, 2009, 10, 1453-1456. doi:10.1002/cbic.200900136

26. A. Tsakiridis, L. M. Alexander, N. Gennet, R. M. Sanchez-Martin, A. Livigni, M. Li, M. Bradley and J. M. Brickman, Biomaterials, 2009, 30, 5853-5861. doi:10.1016/j.biomaterials.2009.06.024

27. L. M. Alexander, S. Pernagallo, A. Livigni, R. M. Sanchez-Martin, J. M. Brickman and M. Bradley, Mol. Biosyst., 2010, 6, 399-409. doi:10.1039/b914428e

28. J. M. Behrendt, D. Nagel, E. Chundoo, L. M. Alexander, D. Dupin, A. V. Hine, M. Bradley and A. J. Sutherland, Plos One, 2013, 8, e50713. doi:10.1371/journal.pone.0050713

29. D. Nagel, J. M. Behrendt, G. F. Chimonides, E. E. Torr, A. Devitt, A. J. Sutherland and A. V. Hine, Mol. Cell. Proteomics, 2014, 13, 1543-1551. doi:10.1074/mcp.0113.034900

30. Nidhi, M. Rashid, V. Kaur, S. S. Hallan, S. Sharma and N. Mishra, Saudi Pharm. J., 2016, 24, 458-472. doi:10.1016/j.jsps.2014.10.001

31. A. Choi, K. D. Seo, D. W. Kim, B. C. Kim and D. S. Kim, Lab Chip, 2017, 17, 591-613. doi:10.1039/c6lc01023g

32. J. Rejman, V. Oberle, I. S. Zuhorn and D. Hoekstra, Biochem. J., 2004, 377, 159-169. doi:10.1042/Bj20031253

33. O. A. Efremova, M. A. Shestopalov, N. A. Chirtsova, A. I. Smolentsev, Y. V. Mironov, N. Kitamura, K. A. Brylev and A. J. Sutherland, Dalton Trans., 2014, 43, 6021-6025. doi:10.1039/C3DT53126K

34. A. O. Solovieva, Y. A. Vorotnikov, K. E. Trifonova, O. A. Efremova, A. A. Krasilnikova, K. A. Brylev, E. V. Vorontsova, P. A. Avrorov, L. V. Shestopalova, A. F. Poveshchenko, Y. V. Mironov and M. A. Shestopalov, J. Mater. Chem. B, 2016, 4, 4839-4846. (C) 2018. This manuscript version is made available under the CC-BY-NC-ND 4.0 license http://creativecommons.org/licenses/by-nc-nd/4.0/ 
doi:10.1039/C6TB00723F

35. Y. A. Vorotnikov, O. A. Efremova, N. A. Vorotnikova, K. A. Brylev, M. V. Edeleva, A. R. Tsygankova, A. I. Smolentsev, N. Kitamura, Y. V. Mironov and M. A. Shestopalov, RSC Adv., 2016, 6, 43367-43375. doi:10.1039/C6RA04321F

36. N. A. Vorotnikova, O. A. Efremova, A. R. Tsygankova, K. A. Brylev, M. V. Edeleva, O. G. Kurskaya, A. J. Sutherland, A. M. Shestopalov, Y. V. Mironov and M. A. Shestopalov, Polym. Adv. Technol., 2016, 27, 922-928. doi:10.1002/pat.3749

37. N. A. Vorotnikova, M. V. Edeleva, O. G. Kurskaya, K. A. Brylev, A. M. Shestopalov, Y. V. Mironov, A. J. Sutherland, O. A. Efremova and M. A. Shestopalov, Polym. Int., 2017, 66, 1906-1912. doi:10.1002/pi.5473

38. M. Ishihara, S. Kishimoto, M. Takikawa, H. Hattori, S. Nakamura and M. Shimizu, Int. J. Mol. Sci., 2015, 16, 11785-11803. doi:10.3390/ijms160511785

39. M. Flinterman, F. Farzaneh, N. Habib, F. Malik, J. Gaken and M. Tavassoli, Mol. Ther., 2009, 17, 334-342. doi:10.1038/mt.2008.256

40. A. L. Fu, R. Tang, J. Hardie, M. E. Farkas and V. M. Rotello, Bioconjugate Chem., 2014, 25, 1602-1608. doi:10.1021/bc500320j

41. C. Mateo, R. Torres, G. Fernandez-Lorente, C. Ortiz, M. Fuentes, A. Hidalgo, F. LopezGallego, O. Abian, J. M. Palomo, L. Betancor, B. C. C. Pessela, J. M. Guisan and R. Fernandez-Lafuente, Biomacromolecules, 2003, 4, 772-777. doi:10.1021/bm0257661

42. J. R. Furtado, Honors Scholar Theses, 2017, 539.

43. D. Pesce, Y. Z. Wu, A. Kolbe, T. Weil and A. Herrmann, Biomaterials, 2013, 34, 43604367. doi:10.1016/j.biomaterials.2013.02.038

44. A. Gautam, J. S. Nanda, J. S. Samuel, M. Kumari, P. Priyanka, G. Bedi, S. K. Nath, G. Mittal, N. Khatri and G. P. S. Raghava, Sci. Rep., 2016, 6, 26278. doi:10.1038/Srep26278

45. S. Schmidt, I. Tavernaro, C. Cavelius, E. Weber, A. Kumper, C. Schmitz, J. Fleddermann and A. Kraegeloh, Nanoscale Res. Lett., 2017, 12, 545. doi:10.1186/S11671-017-2280-9

46. M. Lundqvist, I. Sethson and B. H. Jonsson, Langmuir, 2004, 20, 10639-10647. doi:10.1021/la0484725

47. J. Meissner, A. Prause, B. Bharti and G. H. Findenegg, Colloid Polym. Sci., 2015, 293, 3381-3391. doi:10.1007/s00396-015-3754-х

48. Z. W. Mao, L. Wan, L. Hu, L. Ma and C. Y. Gao, Colloid. Surface. B, 2010, 75, 432-440. doi:10.1016/j.colsurfb.2009.09.017

49. A. T. Bauer, E. A. Strozyk, C. Gorzelanny, C. Westerhausen, A. Desch, M. F. Schneider and S. W. Schneider, Biomaterials, 2011, 32, 8385-8393. doi:10.1016/j.biomaterials.2011.07.078

50. L. Hu, Z. Mao, Y. Zhang and C. Gao, J. Nanosci. Lett., 2011, 1, 1-16.

(C) 2018. This manuscript version is made available under the CC-BY-NC-ND 4.0 license http://creativecommons.org/licenses/by-nc-nd/4.0/ 
51. E. I. Ryabchikova, B. P. Chelobanov, R. G. Parkhomenko, K. V. Korchagina and T. V. Basova, Microporous Mesoporous Mater., 2017, 248, 46-53. doi:10.1016/j.micromeso.2017.04.006

52. R. Levin, S. Grinstein and D. Schlam, Biochim. Biophys. Acta, Mol. Cell. Biol. Lipids, 2015, 1851, 805-823. doi:10.1016/j.bbalip.2014.09.005

53. J. P. Lim and P. A. Gleeson, Immunol. Cell Biol., 2011, 89, 836-843. doi:10.1038/icb.2011.20

54. P. J. Vernon and D. L. Tang, Antioxid. Redox Signal., 2013, 18, 677-690. doi:10.1089/ars.2012.4810

55. L. Gonzalez, S. Corradi and M. Kirsch-Volders, in Nanotoxicology: Progress toward Nanomedicine, Second Edition, eds. N. A. Monteiro-Riviere and C. Lang Tran, CRC Press, 2014, ch. 20, pp. 377-392.

56. L. Gonzalez, M. Lukamowicz-Rajska, L. C. J. Thomassen, C. E. A. Kirschhock, L. Leyns, D. Lison, J. A. Martens, A. Elhajouji and M. Kirsch-Volders, Nanotoxicology, 2014, 8, 876-884. doi:10.3109/17435390.2013.842266

57. J. E. Kim, H. Kim, S. S. A. An, E. H. Maeng, M. K. Kim and Y. J. Song, Int. J. Nanomed., 2014, 9, 235-241. doi:10.2147/Ijn.S57936

58. A. M. Ansari, A. K. Ahmed, A. E. Matsangos, F. Lay, L. J. Born, G. Marti, J. W. Harmon and Z. L. Sun, Stem Cell Rev. Rep., 2016, 12, 553-559. doi:10.1007/s12015-016-9670-8

59. A. M. Cheplakova, A. O. Solovieva, T. N. Pozmogova, Y. A. Vorotnikov, K. A. Brylev, N. A. Vorotnikova, E. V. Vorontsova, Y. V. Mironov, A. F. Poveshchenko, K. A. Kovalenko and M. A. Shestopalov, J. Inorg. Biochem., 2017, 166, 100-107. doi:10.1016/j.jinorgbio.2016.11.014

60. E. V. Svezhentseva, A. O. Solovieva, Y. A. Vorotnikov, O. G. Kurskaya, K. A. Brylev, A. R. Tsygankova, M. V. Edeleva, S. N. Gyrylova, N. Kitamura, O. A. Efremova, M. A. Shestopalov, Y. V. Mironov and A. M. Shestopalov, New J. Chem., 2017, 41, 1670-1676. doi:10.1039/C6NJ03469A 